\title{
Educational Social Mobility in Guatemala: The Social Elevator Walks Slowly.
}

\author{
Guillermo Díaz* \\ Guatemala \\ *Corresponding Author: Guillermo Díaz, Guatemala

\begin{abstract}
The purpose of this article is to describe the evolution of educational social mobility in Guatemala in the years 2000 to 2014, based on the development of a logarithmic regression model and the transition matrices with data from surveys of living conditions for that period. The results show that in this period, although educational social mobility at the country level increased, the rate of increase was low. There is greater educational mobility in men than in women, predominantly ascending short-distance educational mobility. The main conclusion is that the social elevator moves slowly in Guatemala.
\end{abstract}

\section{INTRODUCTION}

During the first three quinquennia of the 21st century, Guatemala experienced changes in social indicators, with a decrease and an increase in poverty and education indicators. According to CEPAL (2014), in the period 1999-2014, while in most Latin American countries there was a continuous decrease and in a significant amount of poverty, from $44 \%$ to $28 \%$, in Guatemala the reduction was by short period and low amount, of eight percentage points. In the case of education, statistics showed a slow increase in coverage indicators, although at the primary level, as in poverty, there was a setback. The purpose of this article is to describe the evolution of poverty and educational social mobility in Guatemala, in the period 2000-2014. For this purpose, educational mobility indexes of the population were estimated and analyzed according to age, sex and ethnic group, among other variables. The indices were calculated based on a transition matrix and estimating a logarithmic regression, where the dependent variable is the education of the child and the explanatory variable the education of the father.

\subsection{The Poverty Trap.}

As a result of the high inequality existing in the distribution of income, the Gini index to 2009 was 0.57 (World Bank, 2009), Guatemala was one of the poorest countries in the Americas. Statistics on poverty reveal that in the past four decades the poverty rate has been reduced, but it is still high, around $60 \%$ at 2016 (INE, 2015). Towards the end of the 1970s it was estimated that $79 \%$ of the population was in a state of poverty, of which $52 \%$ corresponded to extreme poverty (CIDE, 1982). By 1989, the picture of poverty presented an important change, since $63 \%$ of the population, equivalent to 5.5 million people, was in a situation of poverty. Of these, almost half ( 2.8 million) were in extreme poverty, since their per capita income was less than one dollar per day. New studies revealed that poverty fell to 57\% in 2000 and to 51\% in 2006 (UNDP, 2008). However, the number of people who were below the poverty line remained high, equivalent to 6.6 million people in 2006 , that is, in absolute terms the number of poor people increased. The most recent study of the INE (2015) revealed that the magnitude of poverty in Guatemala is 59\%, higher than the rate observed in 2006 (see Figure 1). As for extreme poverty, it was reduced by almost one percentage point in the period 2000-2006, to increase eight percentage points, (23\%) in 2014. 


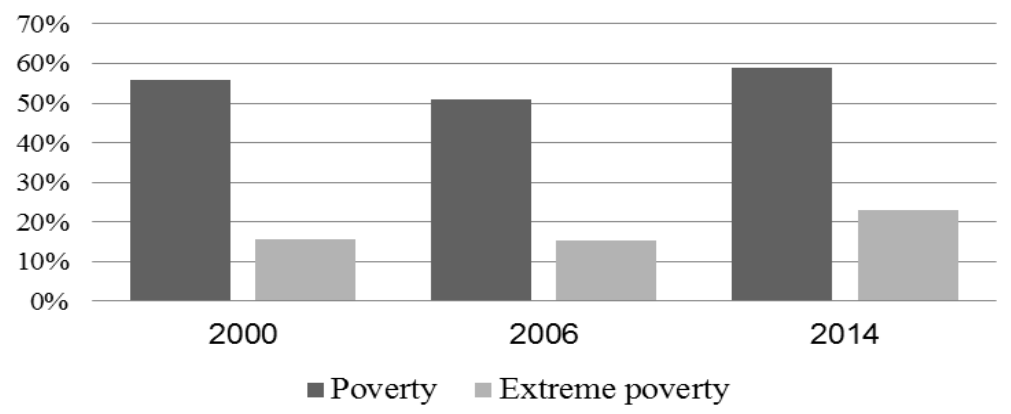

Figure1. Guatemala: Poverty rate. Period: 2000-2014.

Source: INE, 2015 .

The evolution of the poverty rate in the period 2000 to 2014, (Figure 1), revealed that large sectors of the population were in a poverty trap, in the sense that they systematically faced difficulties in achieving minimum levels of well-being. in time (Barrientos, 2007). The poverty trap concept refers to conditions of low socioeconomic mobility, that is, members of a family are trapped in poverty from generation to generation. A determining factor in the intergenerational transmission of poverty is that families do not have the resources to accumulate capital, particularly human capital. The economic needs of the family cause children and young people to leave education to work, so their educational level as parents will be low and will affect their children's low educational level. In Colombia, Nina and Grillo (2000) investigated the relationship between education, social mobility and poverty trap, determining that the poorest $30 \%$ of the population has a high degree of immobility or social inheritance, that is, the children reproduced the level educational of parents. In Mexico, Martell (2016) analyzed poverty traps at a regional level, identifying their existence at the geographic level, in the Central and South zones. The aforementioned author also states that in the period 1989-2000 the percentage of adults between 25 and 30 years of age with full secondary education remained stable, a phenomenon that is identified as a long-term poverty trap, because the population remains at that level educational.

\subsection{Evolution of Education}

Access to education in Guatemala in the period 2000 to 2014 showed growth, although the rate slowed down over time and in the case of primary education was reduced (see Figure 2). The net coverage rate, which includes the student population with respect to the population of study age, decreased as the educational level increased. In 2001 the net coverage rate of primary education was $86 \%$ and increased to a maximum of $97 \%$ in 2009, then decreased to $93 \%$ in 2011 and $85 \%$ in 2014 . At the basic level, which includes three years of study, the net coverage rate increased steadily from $29 \%$ to $44 \%$ between 2001 and 2014. These data reflected that school attendance was reduced by almost half, from the primary level to the basic level, and from this to the diversified or pre-university level (from 16\% to 24\% between 2001 and 2014). This means that in Guatemala the right to education is not guaranteed to all members of society. From another perspective, this fact allows us to interpret education as a privilege of a part of society.

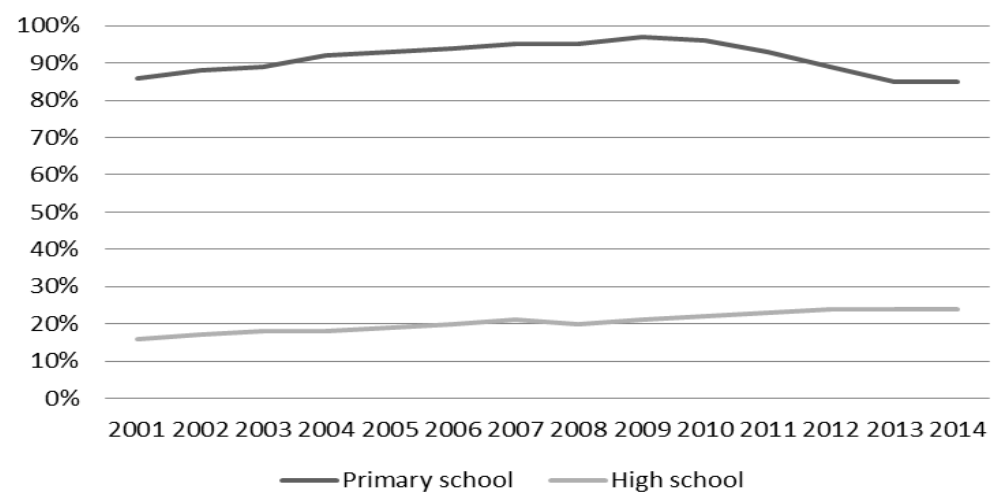

Figure2. Guatemala: Net rate of educational coverage, period 2000-2014.

Source: Ministry of Education, 2014. 


\subsection{Quantification of Social Mobility.}

Bendix and Lipset (1969) and Mayer (1976) define social mobility as the process by which people pass from one social stratum to another, as well as the movement of indicators of socioeconomic status over time, including education (Conconi, Cruces, Olivieri and Sánchez, 2008). Mobility can be horizontal when the individual moves from one position to another as the origin, or vertical, which involves the transition from one social stratum to another. It can also be ascending or descending, individual or group, and can occur in the economic, occupational, political or other. The social mobility of the individual can occur between generations, more specifically between father and son, due to change of occupation, social class or other variable throughout the life of the individual, being of intragenerational type. On the other hand, there is absolute and relative mobility. The first refers to the absolute number, usually expressed in relative terms of a social class that move, while the second deals with the probability of people moving from their social class of origin to another class (Sorokin, 1956).

There are several theories that seek to explain the causes of social mobility. One of the most widespread is the so-called liberal theory that supports the existence of a strong connection between industrialization and social mobility. The liberal theory holds that in industrial societies there is a greater equality of mobility opportunities than in non-industrial ones. Economic development, especially the growth of the services sector, generates the conditions for the increase of technical and professional occupations (Echeverría, 1999). In sociology, there are multiple approaches, both quantitative and qualitative, to quantify and study the social mobility of a given society. Barber (1964) illustrated the use of occupational transition matrices between parents and children in various studies.

\section{Methodology}

For the realization of this research a transition matrix was applied, which according to Cachón (2001) of rows (categories of origin, for example, father's education) and columns (target categories, for example, son's education). The interpretation of the matrix is illustrated in Figure 3, where the variable identified with the letter a shows the total of individuals, the rectangle identified with the letter $\mathrm{b}$ shows the total of individuals in the category of origin and the one identified with the letter $\mathrm{c}$, the total of individuals in the destination category. The diagonal that contains the letter d shows the total of individuals that maintain the same position of origin; while the triangle with the letter e1 identifies upward mobility and the letter e2 identifies downward mobility.

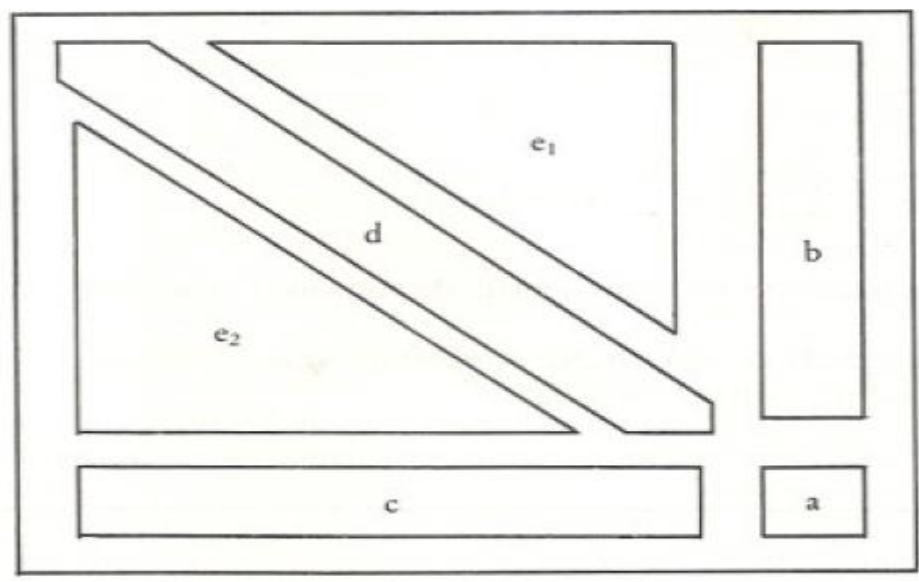

Figure3. Transitions matrix.

Source: Cachón, 2001.

Based on the matrix, the following indices are calculated:

1) Gross stability index: $G S I=\sum_{i=1}^{k} n_{i i}$

2) Gross mobility index: $G M I=\frac{N-\sum_{i, j=1}^{k} n_{i j}}{N}$ 
3) Upward mobility $\quad$ index: $\quad U M I=\frac{\sum_{i, j=1}^{k} n_{i j}}{N}, \quad$ when $\quad \mathrm{j}>\quad 1$
4) Descending mobility index: $D M I=\frac{\sum_{i, j=1}^{k} n_{i j}}{N}$, when $\mathrm{j}<1$

From the transition matrices the mobility index proposed by Shorrocks (1978) can also be obtained: Where: $0 \mathrm{M}(\mathrm{P}) 1, \mathrm{n}=$ number of ranges, Trace $(\mathrm{P})=$ sum of the diagonal of the matrix If the obtained index is equal to one shows a total or perfect mobility, while its value is zero it shows no mobility, which implies the existence of a closed society.

Solon (1992) used logarithmic regressions to measure the inter-generational mobility of income in the United States of America, as did Mediavilla (2004) to measure educational mobility in Brazil, in the following way:. The terms and represent the educational level of children and parents, respectively, measured in logarithms and as a deviation from the respective means. The indicates the degree of educational intergenerational persistence. Consequently, 1 - expresses the degree of educational mobility between generations.

Data from the National Survey of Living Conditions (Encovi) for the years 2000, 2006 and 2014 (INE, 2002, 2007 and 2015) were used, corresponding to the variables: age, sex, educational level of the father, educational level of the mother, educational level of the interviewee, place of residence and ethnic group, of people over 25 years of age. A logarithmic regression was developed to measure the educational social mobility of children with respect to parents, based on Solon (1992) and Mediavilla (2004), and transition matrices were used to disaggregate educational social mobility, through indexes of upward, downward, short and long distance mobility.

\section{Results}

The results obtained in the different regressions (see Table 1) indicate that the father's education explained, in the year 2000, between $15 \%$ and $37 \%$ the educational level of the children. The degree of determination (R2) was lower in the indigenous ethnic group and in the rural area, as well as higher in women, and in the urban area. In the age variable, the results indicate a greater goodness of fit in the cohort of more than 40 years, with R2 equal to 0.35 . The education mobility rate was 0.30 in the country.

Table1. Educational social mobility of adults over 25 years old, year 2000.

\begin{tabular}{|l|l|l|l|r|}
\hline Variable & Beta & Mobility & $\mathrm{R}^{2}$ & Observations \\
\hline Country & $0.70^{*}$ & 0.30 & 0.34 & 9,808 \\
\hline Mens & $0.67^{*}$ & 0.33 & 0.32 & 4,601 \\
\hline Women & $0.72^{*}$ & 0.28 & 0.37 & 5,207 \\
\hline Not indigenous & $0.62^{*}$ & 0.39 & 0.33 & 5,370 \\
\hline Indigenous & $0.61^{*}$ & 0.39 & 0.17 & 4,438 \\
\hline Over 40 years old & $0.73^{*}$ & 0.27 & 0.35 & 5,772 \\
\hline Under 40 years old & $0.61^{*}$ & 0.39 & 0.30 & 4,036 \\
\hline Urban & $0.68^{*}$ & 0.33 & 0.36 & 2,671 \\
\hline Rural & $0.54^{*}$ & 0.46 & 0.15 & 7,137 \\
\hline <p0.05 & \multicolumn{2}{l}{} \\
\hline \multicolumn{5}{|l|}{ Source: Own elaboration, with base Encovi 2000. (INE, 2002). } \\
\hline
\end{tabular}

In 2000, educational mobility in Guatemala was much lower than in other Latin American countries. In fact it was almost half the average of the sample of 6 countries shown in Figure 3. This is not surprising given the high level of poverty in the country. In that year Guatemala was the country with the highest level of poverty in that group. In Guatemala, poverty limits access to education. The lack of employment and income are the two main factors of school dropout (see table 8). 


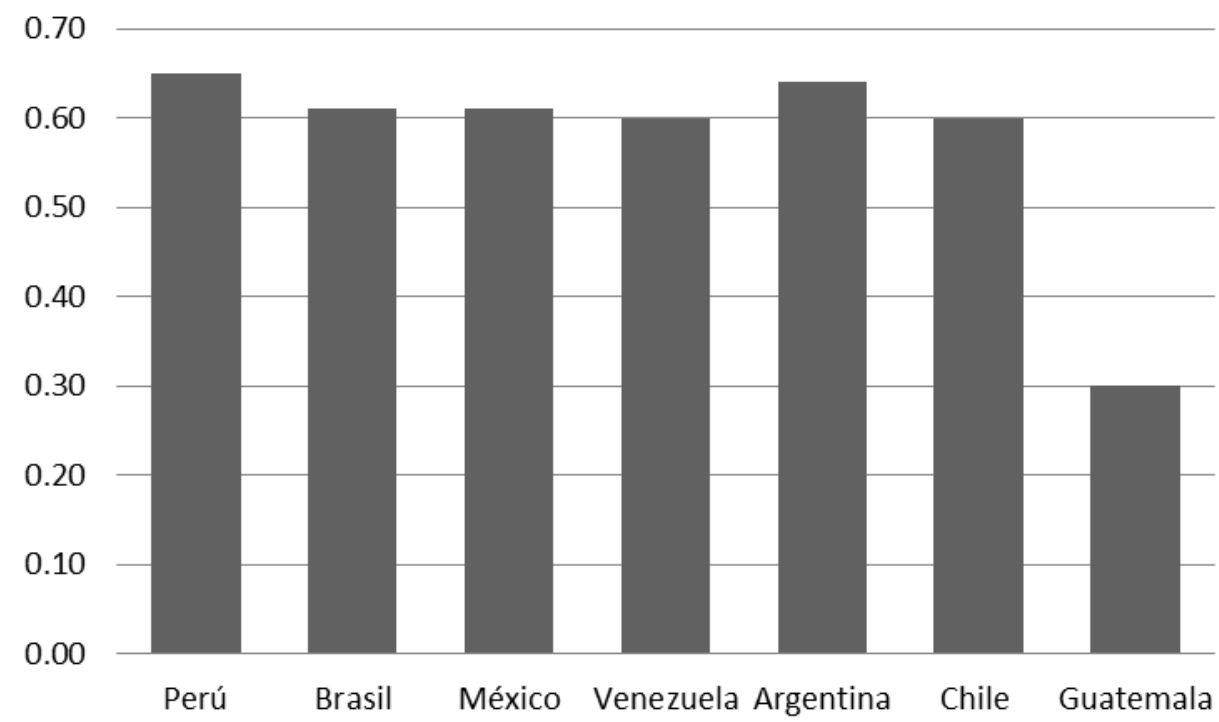

Figure3. Guatemala and other countries: Educational mobility rate. Year 2000.

Source: Ministry of Education, 2014 and Mediavilla \& Calero, 2010.

The transition matrix (see Table 2) shows immobility indices that imply a probability of at least $50 \%$ that the children replicate the father's education; in the cases of primary and university education it is almost 60\%, reaffirming the findings of Solon (1992), however in Guatemala the probability of university children with parents of primary education is very low (0.01), much smaller than other countries in Latin America.

Table2. Transition matrix of parent-child eudcation, over 25 years old, year 2000.

\begin{tabular}{|l|l|l|l|}
\hline Fatherlson & Primary & High school & College \\
\hline Primary school & $\mathbf{0 . 6 0}$ & 0.04 & 0.01 \\
\hline High school & 0.03 & $\mathbf{0 . 5 3}$ & 0.31 \\
\hline College & 0.01 & 0.36 & $\mathbf{0 . 6 1}$ \\
\hline
\end{tabular}

Source: Own elaboration, with base Encovi 2000. (INE, 2002).

Figure 4 shows that in Guatemala the probability of finishing school was much lower in 2000 than in other Latin American countries in those years, when the father has a primary education. This result implies that in Guatemala the poverty trap is greater.

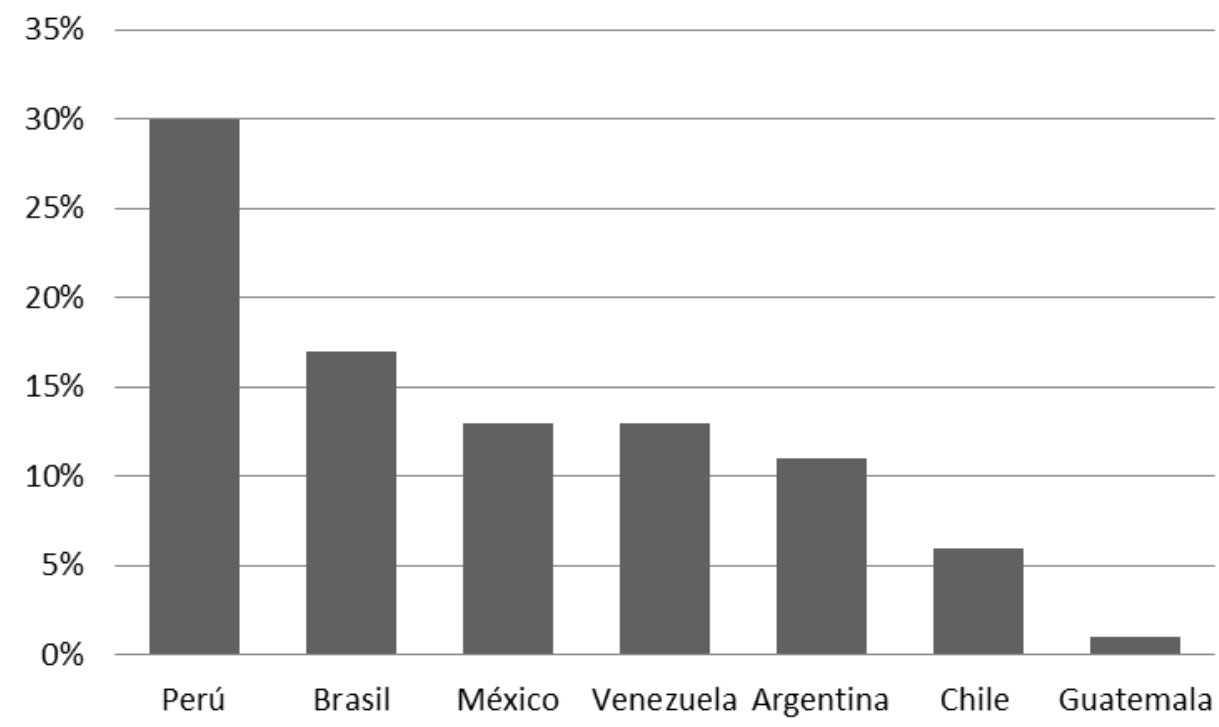

Figure4. Guatemala and other countries: Probability of children finishing college, when the father has a primary education. Year 2000.

Source: Ministry of Education, 2014 and Mediavilla \& Calero, 2010. 
From the transition matrix, the ascending and descending mobility indices were calculated (see Table 3 ), the first being higher (0.381) and explaining $88.4 \%$ of the educational social mobility. However, it is observed that short distance mobility predominated and long distance mobility was reduced.

Table3. Index of educational social mobility, year 2000

\begin{tabular}{|l|l|l|}
\hline \multicolumn{2}{|c|}{ Index } & Explained percentage of mobility \\
\hline Mobility & $\mathbf{0 . 4 3 1}$ & \\
\hline Upward mobility & 0.381 & $88.40 \%$ \\
\hline Downward mobility & 0.050 & $11.60 \%$ \\
\hline Short distance mobility & 0.374 & $86.80 \%$ \\
\hline Long distance mobility & 0.057 & $13.20 \%$ \\
\hline Source: Own elaboration, with base Encovi 2000. (INE, 2002). \\
\hline
\end{tabular}

Although in 2006 mobility in Guatemala was 0.36, higher than in 2000, the existence of low educational social mobility was reaffirmed. The unequal educational mobility in favor of men persisted, 0.38 against 0.26 for women, which meant that the gap was extended to twelve percentage points in six years, and this time there were differences among ethnic groups, being higher for women. Indigenous as for the transition matrix, it again confirmed a low probability of university children with parents of primary education. The mobility index in 2006 was 0.44 , similar to that of the year 2000 and the upward mobility index was 0.39 and explained $88 \%$ of the educational mobility. Long-distance mobility remained low.

In the period from 2006 to 2014 , educational social mobility at the country level amounted to 0.44 (see Table 4), however the coefficient of determination reveals that the power to explain the influence of father's education on children's education decreased. The educational social mobility of men continued to be greater than that of women, although the difference was reduced to eight percentage points from twelve percentage points in 2006; The same can be said in the categories of ethnic group and place of residence. On the contrary, the difference between age cohorts was extended in favor of those under 40 years of age.

Table4. Educational social mobility of adults over 25 years old, year 2014.

\begin{tabular}{|l|l|l|l|l|}
\hline Variable & Beta & Mobility & $\mathrm{R}^{2}$ & Observations \\
\hline Country & $0.56^{*}$ & 0.44 & 0.21 & 17,938 \\
\hline Mens & $0.54^{*}$ & 0.46 & 0.21 & 8,244 \\
\hline Women & $0.62^{*}$ & 0.38 & 0.2 & 9,694 \\
\hline Not indigenous & $0.51^{*}$ & 0.49 & 0.21 & 11,492 \\
\hline Indigenous & $0.55^{*}$ & 0.45 & 0.12 & 6,393 \\
\hline Over 40 years old & $0.61^{*}$ & 0.39 & 0.22 & 10,299 \\
\hline Under 40 years old & $0.44^{*}$ & 0.56 & 0.17 & 7,115 \\
\hline Urban & $0.52^{*}$ & 0.48 & 0.23 & 7,815 \\
\hline Rural & $0.49^{*}$ & 0.51 & 0.12 & 10,123 \\
\hline <p0.05 & & & \\
\hline Source: Own elaboration, with base Encovi 2000. (INE, 2002). & & \\
\hline
\end{tabular}

The transition matrix (see Table 5) has a lower rate of reproduction in primary education and a higher probability that children of parents with primary education can access a higher educational level. The probability of university children of parents with primary education was small, 0.06.

Table5. Transition matrix of parent-chil education of adults over 25 years old, year 2014.

\begin{tabular}{|l|r|r|r|}
\hline Fether/son & Primary & High school & College \\
\hline Primary school & 0.56 & 0.38 & 0.06 \\
\hline High school & 0.13 & 0.59 & 0.28 \\
\hline College & 0.05 & 0.36 & 0.59 \\
\hline Source: INE, 2015. & & & \\
\hline
\end{tabular}

Table 6 shows stagnation in the mobility index (0.43) and the predominant mobility continued being the short-distance ascending type, that is, the children increased their education with respect to the father in an educational level. Although long-distance mobility increased, the increase recorded was reduced. 
Educational Social Mobility in Guatemala: The Social Elevator Walks Slowly.

Table6. Index of educational social mobility, year 2014.

\begin{tabular}{|l|l|l|}
\hline \multicolumn{2}{|c|}{ Index } & Explained percentage of mobility \\
\hline Mobility & $\mathbf{0 . 4 3}$ & \\
\hline Upward mobility & 0.39 & $90.60 \%$ \\
\hline Downward mobility & 0.04 & $9.40 \%$ \\
\hline Shor distance mobility & 0.38 & $88.40 \%$ \\
\hline Long distance mobility & 0.05 & $11.60 \%$ \\
\hline Source: Own elaboration, with base Encovi 2014. (INE, 2015). \\
\hline
\end{tabular}

\subsection{The Social Elevator Walks Slow}

In the first decade and a half of the 21st century there was a growing trend in educational social mobility in Guatemala (see Table 7), as well as in ethnic groups, however in the Indigenous category there was stagnation. According to sex, it increased more for women than for men, the gap narrowed but in the end mobility was higher in men. With respect to the age cohort, mobility was greater among those who are 40 or less years old, and the gap in favor of these was widened. In the rural area, mobility increased more than in the urban area.

Table7. Educational social mobility, years 2000, 2006 y 2014.

\begin{tabular}{|l|l|l|l|l|l|}
\hline Variable & Year 2000 & Year 2006 & Year 2014 & Change \\
\hline Country & 0.30 & 0.36 & 0.44 & 0.06 & 0.08 \\
\hline Indigenous & 0.39 & 0.45 & 0.45 & 0.06 & 0 \\
\hline Not indigenous & 0.38 & 0.41 & 0.49 & 0.03 & 0.08 \\
\hline Mens & 0.33 & 0.38 & 0.46 & 0.05 & 0.08 \\
\hline Women & 0.19 & 0.26 & 0.38 & 0.07 & 0.12 \\
\hline Under 40 years old & 0.39 & 0.45 & 0.56 & 0.06 & 0.11 \\
\hline Over 40 years old & 0.27 & 0.33 & 0.39 & 0.06 & 0.06 \\
\hline Urban & 0.32 & 0.38 & 0.48 & 0.06 & 0.10 \\
\hline Rural & 0.46 & 0.48 & 0.51 & 0.02 & 0.03 \\
\hline \multicolumn{2}{|l}{ Source: Own elaboration, with base Encovi 2000, 2006 y 2014. (INE, 2002, 2007 y 2015). } \\
\hline
\end{tabular}

The low rate of educational social mobility in the period analyzed is explained, among others, by low economic growth and school dropout. In the first case, the average rate of economic growth for the period was $3.5 \%$, higher by half a percentage point of population growth. Consequently, the demand for work, especially technical and professional positions, grew at a moderate pace. The participation of the public sector in the GDP structure increased only one percentage point, while that of the financial services sector increased by three percentage points in the period under investigation. In the second case, the causes of school dropout were mainly economic, work and lack of money (see Table 8). Consequently, the conditions for a strong connection between development and social mobility, in this case, educational, as the liberal theory maintains (Echeverría, 1999), did not exist in the country.

Table8. Guatemala: Reasons to drop out of school.

\begin{tabular}{|l|l|}
\hline Reason & Percentage \\
\hline Job & $32 \%$ \\
\hline Lack of money & $31 \%$ \\
\hline Housework & $16 \%$ \\
\hline It's not interesting to study & $12 \%$ \\
\hline Others & $9 \%$ \\
\hline Total & $100 \%$ \\
\hline Source: Own elaboration, with base Encovi 2014 (INE, 2015). \\
\hline
\end{tabular}

\subsection{Mobility or Social Reproduction?}

Following Bordieu and Passeron (1996), the question arises: Can the indices of low educational social mobility be interpreted as an expression of the reproduction of social inequalities existing in the country? Empirical evidence suggests that the answer is yes, since short distance mobility predominates over long distance mobility. This means that the children of parents with little education have a low probability of attaining higher education; As reflected in the transition matrices, it is almost certain that one out of every two people reproduces the educational level of the father, only one in sixteen will achieve a bachelor's degree or equivalent. The children of parents with this educational level will reproduce the same level in one of every two cases, only one of every three will 
be able to enter the university; while the children of parents with university studies will reproduce this level in two out of three cases. In Guatemala, more than talking about educational social mobility, one must speak of educational social reproduction.

\subsection{Relationship Education and Self-Class Affiliation}

Finally, the relationship between education and class self-ascription is described (see Figure 5). The people with primary education identify themselves more as members of the lower class, while the people with secondary and university education identify themselves more as members of the middle class, according to a sample of 1844 people asked in 2014 and 2015 (Latinobarometro, 2015 and 2016) . In Latin America, this relationship also occurs, although in a greater percentage. In the first case it is $64 \%$ against $52 \%$ in Guatemala.

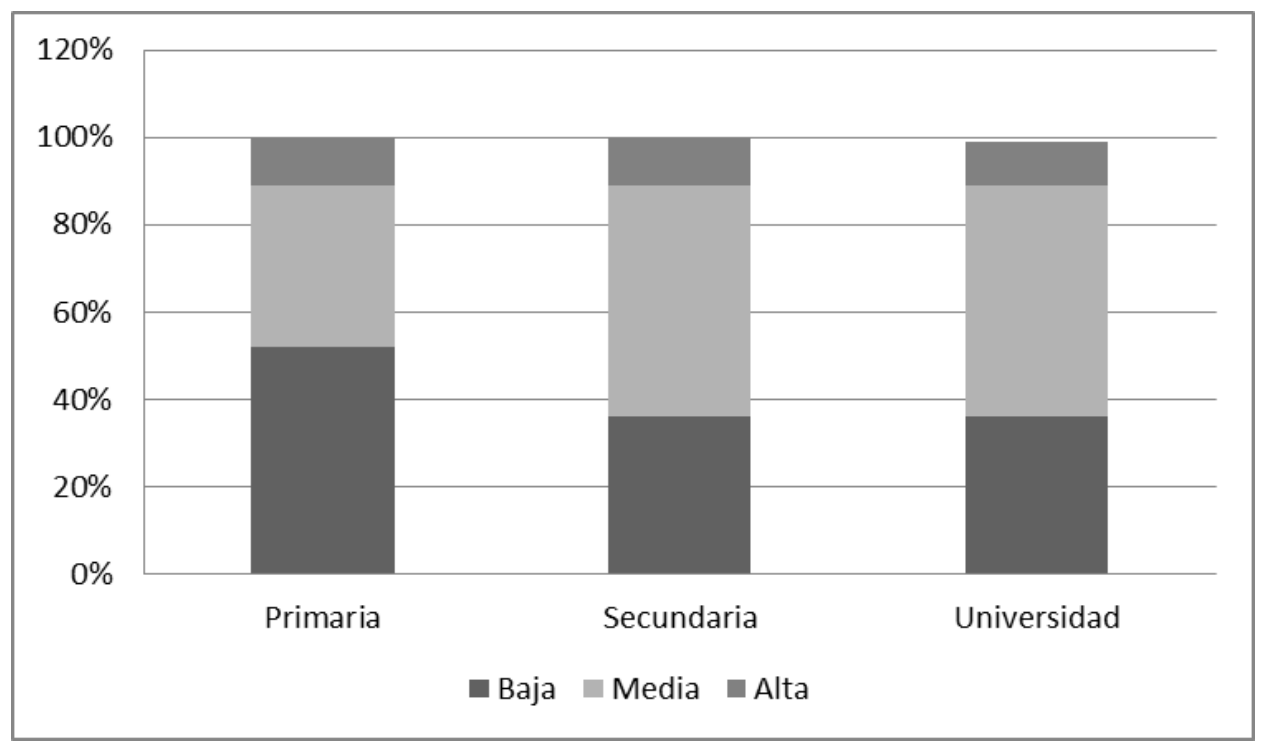

Figure5. Guatemala: Self-class affiliation according to educational level. Year 2014-2015.

Source: Latinobarometro, 2016

Based on the above data, it can be interpreted that less educational mobility also implies less social mobility. In fact, it implies a lower probability of getting out of poverty. A person with primary education has a $67 \%$ chance of living in poverty, if they have high school, the probability is reduced to 395 and only $5 \%$ if they have a university study, according to their own calculations based on life conditions surveys

\section{CONCLUSION}

The poverty trap is observed in the reasons of the Guatemalans to abandon their studies, work and lack of money, giving indications that people do not study because they lack the resources to do so. The estimates made in this study show that the education of the father affects the children's education, although its influence was reduced during the period of analysis, and that the educational mobility in Guatemala is low and increases slowly, which reflects the reproduction of a dynamic of social exclusion.

A high percentage of the country's population experiences poverty trap education; a child whose father only has a primary education, to 2014 , had a $6 \%$ probability of reaching university studies, while in 2000 it was $1 \%$, which indicates that the probability of perpetuating the situation of poverty between generations is high, and that the social position of the children is determined, to an important extent, by ascription and not by achievement.

There is a difference in educational mobility between sexes, ages and places of residence, for this reason public policy in Guatemala, especially education, must have as a priority objective to increase the level of education of the population, particularly the young, with the purpose of achieve greater educational mobility. An increase in educational mobility helps overcome the poverty trap in future generations. The greater the educational attainment of the people, the greater will be the probability of their children to reproduce said educational level or overcome it and the lower the probability of being in poverty. 


\section{BIBLIOGRAPHY}

[1] Banco Mundial. (2009). Guatemala. Evaluación de la pobreza. Buen desempeño a bajo nivel. Guatemala, Guatemala: Banco Mundial.

[2] Barrientos, A. (2007). Does vulnerability créate poverty traps? Recuperado de: http://www.chronicpoverty.org/uploads/publication_files/WP76_Barrientos.pdf

[3] Bendix, R. y Lipset, S. (1969). Clase, status y poder. Madrid, España: Euramérica.

[4] Bordieu, P. y Passeron, J. (1996). La reproducción. Elementos para una teoría del sistema de enseñanza. Barcelona, España: Popular.

[5] Cachón, L. (2001). ¿Movilidad social o trayectoria de clase? Madrid, España: Centro de Investigaciones Sociológicas.

[6] CEPAL. (2014). Panorama social de América Latina. Santiago de Chile, Chile: CEPAL.

[7] Centro de Investigación y Docencia Económica-CIDE. (1982). Centroamérica. Crisis y política internacional. México, D. F, México.: Siglo Veintiuno Editores.

[8] Conconi, A., Cruces, G., Olivieri, S., y Sánchez, R. (2008). E pur si mouve? Movilidad, pobreza y desigualdad en América Latina. Económica, 1-2 (LIV): 121-159.

[9] Echeverría, J. (1999). La movilidad social en España (1940-1991). Madrid, España: Ediciones Istmo.

[10] INE. (2002). Encuesta de condiciones de vida ENCOVI 2000. Guatemala, Guatemala: INE.

[11] INE. (2007). Encuesta de condiciones de vida ENCOVI 2006. Guatemala, Guatemala: INE.

[12] INE. (2015). Encuesta de condiciones de vida ENCOVI 2014. Guatemala, Guatemala: INE.

[13] Latinobarometro (2016). Informe latinobarometro 215. Recuperado de http://www.latinobarometro.org/ lat.jsp

[14] Martell, O. (2016). Revisión teórica de la trampa de pobreza y divergencia económica entre las entidades federativas de México. (Tesis de maestría) Tijuana, México: El Colegio de la Frontera Norte. Recuperado de https://www.colef.mx/posgrado/wp-content/uploads/2016/11/TESIS-Martell-Silva-Oscar.pdf.

[15] Mayer, K. (1976) Clase y sociedad. Buenos Aires, Argentina: Paidós.

[16] Mediavilla, M. (2004). Movilidad intergeneracional educativa. Análisis del caso brasileño. Recuperado de www.ual.es/congresos/econogres/docs/Educacion/.../Mediavilla.pdf

[17] Mediavilla, M. y Calero, J. (2010). Movilidad educativa en Latinoamérica. Un estudio para seis países. Revista española de educación compara, 16 (1), 287-303.

[18] Ministerio de Educación. (2014). Boletín estadístico anual. Guatemala, Guatemala: Ministerio de Educación.

[19] Nina, E., \& Grillo, S. (2000). Educación, movilidad social y trampa de pobreza. Bogotá, Colombia: Fedesarrollo. Recuperado de http://www.repository.fedesarrollo.org.co/handle/11445/1770

[20] PNUD. (2008). Guatemala. ¿Una economía al servicio del desarrollo humano? Guatemala, Guatemala: PNUD.

[21] Solon, G. (1992). Intergenerational income mobility in the United States. The America Economic Review, 393 (82), 393-408.

[22] Sorokin, P. (1956). Social Mobility. Illinois, USA: Free Press.

[23] Shorrocks, A. (1978). The measurement of mobility. Econométrica, 5 (46), 1013-1024.

\section{AUTHORS' BIOGRAPHY}

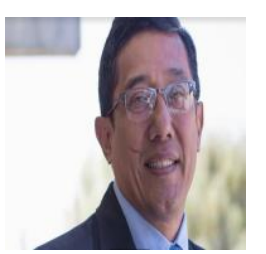

Guillermo Díaz. He is an economist and has a PhD of Sociology from University of Salamanca, Spain, and currently works as professor of economics at the Rafael Landívar University, in Guatemala. He researches the economics and sociology of inequality and development.

Citation: Guillermo Díaz. "Educational Social Mobility in Guatemala: The Social Elevator Walks Slowly." International Journal of Humanities Social Sciences and Education (IJHSSE), vol 7, no. 8, 2020, pp. 71-79. doi: https://doi.org/10.20431/2349-0381.0708008.

Copyright: (c) 2020 Authors. This is an open-access article distributed under the terms of the Creative Commons Attribution License, which permits unrestricted use, distribution, and reproduction in any medium, provided the original author and source are credited. 